\title{
On-farm Assessment of Balanced Crop Nutrition on Productivity and Nutrient Use Efficiency in Rice (Oryza sativa L.) - Horse Gram [Macrotyloma uniflorum (Lam.) Verdc] Cropping System in South Konkan Coastal Zone of Maharashtra
}

\author{
A. V. Dahiphale ${ }^{1 *}$, S. B. Bhagat ${ }^{1}$, N. V. Mhaskar $^{2}$, D. G. Jondhale ${ }^{2}$, \\ T. J. Bedse ${ }^{2}$ and P. B. Vanve ${ }^{2}$ \\ ${ }^{1}$ AICRP-IFS, Regional Agricultural Research Station, \\ Karjat, Dist. - Raigad, Maharashtra, India \\ ${ }^{2}$ Regional Agricultural Research Station, Karjat, Dist. - Raigad Maharashtra \\ Dr Balasaheb Sawant Konkan Krishi Vidyapeeth, Dapoli, India \\ *Corresponding author
}

K e y w o r d s
On farm research,
Rice-horse gram
system, Agronomic
efficiency, Partial
factor productivity,
Marginal returns
Article Info
Accepted:
15 April 2020
Available Online:
10 May 2020

\section{A B S T R A C T}

Enhancing the nutrient use efficiency (NUE) in rice based food production systems of south konkan coastal zone of Maharashtra has always been an area of great focus as costs of production is increasing which ultimately results in reducing the productivity of the area and reduce the response of crop to recommended nutrient management. An experiment 'On farm assessment of plant nutrients in rice -horse gram cropping systems' were conducted during the year 2017-18 through farmer participatory approach in rice based food production systems of south konkan coastal zone of Ratnagiri district of Maharashtra. A total of 24 farmers in six different villages (four per village) of two blocks (Lanja and Rajapur) in area were selected. An experiment in farmers filed on rice-horse gram systems were conducted with various 7 treatments, viz., $\mathrm{T}_{1}$-Control, $\mathrm{T}_{2}$-Recommended $\mathrm{N}$ alone, $\mathrm{T}_{3}$ Recommended $\mathrm{N}$ and $\mathrm{P}, \mathrm{T}_{4}$-Recommended $\mathrm{N}$ and $\mathrm{K}, \mathrm{T}_{5}$-Recommended $\mathrm{N}, \mathrm{P}$ and $\mathrm{K}, \mathrm{T}_{6}$ Recommended NPK with $\mathrm{ZnSO}_{4}$ and $\mathrm{T}_{7}$-Farmers' practice. Results reveled that across the six various villages of the zones and cropping systems, farmers applied lower level of $\mathrm{N}$, $\mathrm{P}_{2} \mathrm{O}_{5}, \mathrm{~K}_{2} \mathrm{O}$ and no amount of micronutrients as per recommendation. Application of recommended dose of NPK and micronutrient in every village in rice-horse gram system recorded higher system rice equivalent yield (REY $\mathrm{kg} / \mathrm{ha}$ ) over the farmer package, appropriate recommended NPK and micronutrients significantly boosted the yield. Improvement in agronomic efficiency (AE) of nitrogen, partial factor productivity of nitrogen and relative response was also reported at upper level with the combination of $\mathrm{NPK}+\mathrm{Zn}$ compared to N, NP and NK alone. Whereas in case of economics incremental benefits were recorded in net returns (rs/ha) and in benefit cost ratio ( $\mathrm{B}: \mathrm{C}$ ratio) at all the location. 


\section{Introduction}

Pulses grown on 22-24 M ha area in country and rice was cultivated on $44.14 \mathrm{~m}$ ha area with production of 111.87 MT. India has achieved noteworthy increase in food production in the post-green revolution phase, from 90 million tonnes in $1969-70$ to 291.95 million tonnes in 2019-20. India is the largest producer $(25 \%$ of global production), consumer (27\% of world consumption) and importer $(14 \%)$ of pulses in the world. In sequential cropping system involving pulses, the preceding pulse may contribute $18-70 \mathrm{~kg}$ $\mathrm{N} / \mathrm{ha}$ to the soil which is made available to the next crop in sequence (Ali and Mishra 2000). Occurrence of multi nutrient deficiency due to imbalanced use of nutrients and declining soil organic matter are the factors affecting the productivity of rice -horse gram cropping sequence at the farmers' field. With a consumption of $16.95 \mathrm{Tg} \mathrm{N}, 6.850 \mathrm{Tg} \mathrm{P} 2 \mathrm{O} 5$ and 2.77 $\mathrm{Tg} \mathrm{K} 2 \mathrm{O}$ in 2017-18. However, nutrient use efficiency (NUE) in India has always been major issue. In the last 35 years, fertilizer response in irrigated areas of the country has declined almost three times from $13.4 \mathrm{~kg}$ grain $/ \mathrm{kg} \mathrm{NPK}$ in 1970 to $3.7 \mathrm{~kg}$ grain/kg NPK in 2005. Nitrogen application has made substantial contribution to the tripling of global food production over the last five decades. However, its use efficiency in agriculture is in general low and ranges between $20 \%$ and $50 \%$. Imbalanced application of essential nutrients (secondary and micro) is one of the reasons for low nitrogen use efficiency. Improved nitrogen management will certainly save the nitrogen loss with increasing in NUE. Time and rate of application is a key for higher profitability and productivity. Proper scheduling of nitrogen is necessary for improving its use efficiency depending on climatic situation, rainfall pattern and soil type (Dahiphale et al., 2018). In Maharashtra, rice is cultivated on 15.56 lakh ha area. In Konkan regions rice was grown on 3.69 lakh ha with the highest productivity of rough rice was in Konkan region 4.25 t ha-1 (Anon. 2017). In konkan region traditional rice based cropping systems followed under residual moisture situations. As horse gram crop are very well known for its ability to improving soil fertility restoration value, deep rooting, nitrogen fixation, leaf shedding ability are some of the focusing issue of the horse gram. Inclusion of horse gram crop in intensive rice based system is step towards integrated plant nutrient supply system. Therefore, horse gram has become viable alternative to improve the soil health and improve nutrient management efficiency in south konkan region. Considering this fact, a farmer's participatory research was carried out at farmers' field to quantify response of the nutrients in rice horse gram cropping system in south konkan region.

\section{Materials and Methods}

An experiment was conducted in (6) six different villages of two blocks of Lanja and rajapur in Ratnagiri district, situated in south costal konkan Zone of Maharashtra on "On farm assessment of plant nutrients in rice horse gram cropping systems under south konkan coastal zone of Maharashtra" to assess the response of rice -horse gram systm to different nutrients combinations during the year 2017-18 at farmers' field. After appropriate bench mark survey of twenty-four (24) farmers were selected from 6 different villages, spread in 2 blocks (Lanja and Rajapur) of Ratnagiri district situated in south konkan coastal zone of Maharashtra adopted by On-Farm Research Centre, All India Coordinated Research Project on Integrated Farming Systems, Dr Balasaheb Sawant Konkan Krishi vidyapeeth, Dapoli. The seven treatments, viz., $\quad \mathrm{T}_{1}$-Control, $\quad \mathrm{T}_{2-}$ Recommended $\mathrm{N}$ alone, $\mathrm{T}_{3}$ - commended $\mathrm{N}$ and $\mathrm{P}, \mathrm{T}_{4}$-Recommended $\mathrm{N}$ and $\mathrm{K}, \mathrm{T}_{5^{-}}$ 
Recommended N, P and $\mathrm{K}, \mathrm{T}_{6^{-}}$ Recommended NPK with $\mathrm{ZnSO}_{4}$ and $\mathrm{T}_{7}$ Farmers' practice were taken for study on each selected farmers field. The soils of the experimental sites was red laterite with $\mathrm{pH}$ 5.24, Electrical conductivity $0.08\left(\mathrm{dS} \mathrm{m}^{-1}\right)$, Organic Carbon $12.5\left(\mathrm{~g} \mathrm{~kg}^{-1}\right)$ and available $\mathrm{N}$, $P$ and $K$ was $290.25,14.05$ and $96.8 .16 \mathrm{~kg}$ $\mathrm{ha}^{-1}$ respectively. In the treatment $\mathrm{T}_{6}$ $\left(\mathrm{NPK}+\mathrm{ZnSO}_{4}\right), \mathrm{ZnSO}_{4}$ was only applied to Kharif rice crop not to the Rabi horse gram. Particulars of farmers' fields with on-farm experiments at six village's locations are given in table 1. Applied recommended levels of $\mathrm{N}, \mathrm{P}, \mathrm{K}$, and $\mathrm{Zn}, \mathrm{Kg} \mathrm{ha}^{-1}$,genotypes grown, duration of genotype and date of transplanting/sowing of rice-horse gram cropping system used are presented in table 2 . In rice-horse gram cropping system the crops production was done by following all standers package of practices. The system productivity was calculated by converting the yield of rice in to rice equivalent yield (REY) of horse gram by. Rice equivalent yield of horse gram crops was calculated by multiplying the yield of the respective crops with their price and then dividing by the price of rice. REY of horse gram $=[$ (horse gram yield $\mathrm{x}$ price of horse gram) / (price of rice)]. In case of nutrient use efficiencies (NUE) of the system it was measured and calculated in terms of Partial Factor Productivity (PFP) $\mathrm{PFP}_{\mathrm{n}}=$ $\mathrm{GY}_{\mathrm{n}} / \mathrm{F}_{\mathrm{n}}$ and Agronomic efficiency (AE) AUE $=\left(\mathrm{GY}_{\mathrm{n}}-\mathrm{GY}_{0}\right) / \mathrm{F}_{\mathrm{n}}$ Where, $\left(\mathrm{PFP}_{\mathrm{n}}\right.$ and $\left.A U E_{\mathrm{n}}\right)$, are the partial factor productivity and agronomic use efficiency of $\mathrm{N}$. In case of the $\mathrm{GY}_{0}$ and $\mathrm{GY}_{\mathrm{n}}$ are the yields of the respective treatments (control, $\mathrm{N}$ alone) and $\mathrm{F}_{\mathrm{n}}$ are the amounts of nitrogen applied to particular treatment. The quantity of all nutrients input and economic outputs are expressed in $\mathrm{kg}$ ha 1. Relative yield responses (RR) to different nutrient combinations were calculated by using the formula of [grain yield (treatment $X)$ - grain yield (control)]/ grain yield (control) where, treatment $\mathrm{X}$ represents $\mathrm{N}$,
NP, NK and NPK application (Tittonell et al., 2008). Marginal returns (MR) for the treatment over the control was calculated as $\mathrm{MR}=\left[\left(\mathrm{NR}_{\mathrm{t}}-\mathrm{NR}_{\mathrm{c}}\right) /\left(\mathrm{CC}_{\mathrm{t}}-\mathrm{CC}_{\mathrm{c}}\right)\right] \times 100$, where $\mathrm{NR}_{\mathrm{t}}$ and $\mathrm{NR}_{\mathrm{c}}$ are Net returns of treatment and control respectively while $\mathrm{CC}_{\mathrm{t}}$ and $\mathrm{CC}_{\mathrm{c}}$ are cost of cultivation of treatment and control respectively. Regarding statistical analysis, each farmer experimental plot were considered as a replication at each location and randomized block design (RBD) was used for statistical comparisons. Descriptive statistical analysis was used for different parameters to establish the range of variability and deviation with in location using standard error of mean. Thereafter, the Randomized Block Design was used to compare treatment means within and between the locations.

\section{Results and Discussion}

\section{Rice Equivalent System Yield (RESY)}

In case of Rice -horse gram cropping system (RHCS) yield it was calculated in terms of rice equivalent system yield (Tanle-3). Rice horse gram cropping system responded significantly positively with the addition of recommended quantity of $\mathrm{N}, \mathrm{P}$ and $\mathrm{K}$. Among all treatments application of balanced dose of fertilizers along with micronutrients $\left(\mathrm{T}_{6}\right)$ recorded highest rice equivalent system yield followed by the treatment $\mathrm{T}_{5}$ and among the selected villages, Panhale village of Rajapur block recorded higher rice equivalent system yield (RESY) of $6105.2 \mathrm{~kg} / \mathrm{ha}$ with recommended quantity of NPK with $\mathrm{ZnSO} 4$ application followed by village Asage in same block in case of Lanja block village Unhale $(5817.2 \mathrm{~kg} / \mathrm{ha})$ followed by village Parule as Rajapur block is having higher productive soils compare to Lanja block. The higher levels of yield observed with application of NPK with $\mathrm{ZnSO} 4$ at all the locations. It may be due to the involvement of $\mathrm{P}$ in vigorous root development and proper absorption of $\mathrm{N}$, 
as $\mathrm{K}$ is involved in $\mathrm{N}$ metabolism in rice crop and $\mathrm{P}$ plays vital role in improving productivity of horse gram. Balanced NPK fertilizers application along with $\mathrm{ZnSO}_{4}$ is an essential management practice for rice-horse gram system to achieve the higher productivity and profitability of the system, similar findings were reported by Ghosh et al., (2004) and Prasad et al., (2004) (Table 3).

\section{Partial factor productivity (PFP)}

Regarding partial factor productivity (Table 4) it was recorded at higher side with the treatment $\left(\mathrm{T}_{6}\right)$ balanced NPK fertilizers application along with $\mathrm{ZnSO}_{4}$ as compared to application of nitrogen alone, combination of nitrogen + phosphorus, nitrogen + potassium and application of NPK in combination. Partial factor productivity of nitrogen (PFPn) can be increased from $48.02 \%$ to $43.79 \%$ in Kharif rice crop and $26.09 \%$ to $24.44 \%$ in horse gram crop when treatment $\mathrm{T}_{6}$ was impose to the rice -horse gram cropping system as compared to application of nitrogen alone, combination of NP and combination of NK in rice- horse gram cropping system in all villages of study area. Appropriate balance of nutrients applied in soil play significant role in improving the recovery of NPK from applied fertilizers and from native soils it is obvious from the estimation of PPFn of ricehorse gram cropping system with application of balanced NPK fertilizers application along with $\mathrm{ZnSO}_{4}$, similar findings were recorded by Haerdter and Fairhurst (2003).

\section{Agronomic efficiency (AE)}

Estimation of an incremental efficiency from applied Nitrogen, over control, was done in our study, it was noticed that apart from of fertilizer treatments, calculated agronomic use efficiency of applied $N\left(A_{U} E_{n}\right)$ is greater in rice than in horse gram at all locations (Table 5). In study area it was observed that farmers are habitual of applying only $\mathrm{N}$ fertilizers only. AUEn can be increased from $26.48 \%$ to $21.58 \%$ in Kharif rice crop and $15.58 \%$ to $14.26 \%$ in horse gram crop when treatment $\mathrm{T}_{6}$ was impose to the rice -horse gram cropping system as compared to application of nitrogen alone, combination of $\mathrm{NP}$ and combination of $\mathrm{NK}$ in rice- horse gram cropping system in all villages of study area. Data indicated that application of NP or NK had recorded considerable increase in AUE of $\mathrm{N}$ at all the locations of study area as compared to application of $\mathrm{N}$ alone, the magnitude of increase in AUE was meager than the balanced application of NPK+micronutrient. Panwar et al., (2019) recorded similar findings which are in conformity with results noted.

\section{Relative response (RR)}

Relative response (Table 6) of balanced application of nutrients along with micronutrients over control recorded similar results as that of PFP and AE. Relative response of application of NPK + deficient micronutrients over control was in the range of 0.98 to 1.24 these results are in conformity with the findings of (Ravisankar et al., 2014) Among the all villages Parule location of block Lanja had recorded higher relative response of with NPK over control it might be due to the fact of effective resource utilization of nutrients. It is also evident from higher PPF to the rice-horse gram cropping system.

\section{Marginal returns}

In case of estimated cost of cultivation it was higher in treatment $\left(\mathrm{T}_{6}\right)$ balanced NPK fertilizers application along with $\mathrm{ZnSO} 4$ at all the locations of the study area and it was ranged from 117971.2 /ha in Unhale village of Rajapur block to $117089.7 /$ ha in Asage village of Lanja block (Table 7). 
Table.1 Particulars of farmers' fields with on-farm experiments at six village's locations in Ratnagiri district of Maharashtra

\begin{tabular}{|c|c|c|c|c|c|c|c|c|c|c|c|c|}
\hline \multirow[t]{3}{*}{ Characteristics } & \multicolumn{6}{|c|}{ Lanja Block } & \multicolumn{6}{|c|}{ Rajapur block } \\
\hline & \multicolumn{2}{|c|}{ Veral } & \multicolumn{2}{|c|}{ Asage } & \multicolumn{2}{|c|}{ Panhale } & \multicolumn{2}{|c|}{ Unhale } & \multicolumn{2}{|r|}{ Parule } & \multicolumn{2}{|c|}{ Shedhe } \\
\hline & Rice & Horse gram & Rice & Horse gram & Rice & Horse gram & Rice & Horse gram & Rice & Horse gram & Rice & Horse gram \\
\hline $\mathrm{N}$ & 82.5 & 10 & 82.5 & 10 & 82.5 & 10 & 82.5 & 10 & 82.5 & 10 & 82.5 & 10 \\
\hline $\mathrm{P}$ & 25 & 20 & 25 & 20 & 25 & 20 & 25 & 20 & 25 & 20 & 25 & 20 \\
\hline $\mathrm{K}$ & 0 & 0 & 0 & 0 & 0 & 0 & 0 & 0 & 0 & 0 & 0 & 0 \\
\hline $\mathrm{Zn}$ & 0 & 0 & 0 & 0 & 0 & 0 & 0 & 0 & 0 & 0 & 0 & 0 \\
\hline Soil texture & \multicolumn{2}{|c|}{ Red ferruginous } & \multicolumn{2}{|c|}{ Red ferruginous } & \multicolumn{2}{|c|}{$\begin{array}{c}\text { Red } \\
\text { ferruginous }\end{array}$} & \multicolumn{2}{|c|}{ Red ferruginous } & \multicolumn{2}{|c|}{ Red ferruginous } & \multicolumn{2}{|c|}{ Red ferruginous } \\
\hline $\mathrm{pH}$ & \multicolumn{2}{|c|}{6.38} & \multicolumn{2}{|c|}{6.55} & \multicolumn{2}{|c|}{6.20} & \multicolumn{2}{|r|}{6.69} & \multicolumn{2}{|r|}{7.28} & \multicolumn{2}{|r|}{7.05} \\
\hline $\mathrm{OC}(\%)$ & \multicolumn{2}{|c|}{0.51} & \multicolumn{2}{|c|}{0.66} & \multicolumn{2}{|c|}{0.41} & \multicolumn{2}{|r|}{0.64} & \multicolumn{2}{|r|}{0.81} & \multicolumn{2}{|r|}{0.65} \\
\hline $\mathrm{N}(\mathrm{kg}$ ha & \multicolumn{2}{|c|}{249.63} & \multicolumn{2}{|c|}{225.79} & \multicolumn{2}{|c|}{233.32} & \multicolumn{2}{|c|}{219.52} & \multicolumn{2}{|r|}{283.49} & \multicolumn{2}{|r|}{270.95} \\
\hline $\mathrm{P}$ (kg ha & \multicolumn{2}{|c|}{11.65} & \multicolumn{2}{|c|}{9.58} & \multirow{2}{*}{\multicolumn{2}{|c|}{9.68}} & & 10.19 & & 11.99 & & 11.47 \\
\hline $\mathrm{K}(\mathrm{kg}$ ha & & 5.71 & & 7.25 & & & & 190.43 & & 195.71 & & 186.39 \\
\hline
\end{tabular}

Table.2 Recommended levels of N, P, K, and Zn, genotype and date of transplanting of rice- horse gram cropping system in Ratnagiri district of Maharashtra

\begin{tabular}{|c|c|c|c|c|c|c|c|c|c|c|c|c|c|c|}
\hline \multirow[t]{3}{*}{ Location } & \multicolumn{7}{|c|}{ Rice } & \multirow{3}{*}{ Variety } & \multicolumn{6}{|c|}{ Horse gram } \\
\hline & \multirow[t]{2}{*}{ Variety } & \multirow[t]{2}{*}{$\begin{array}{l}\text { Duration } \\
\text { in days }\end{array}$} & \multicolumn{4}{|c|}{$\begin{array}{l}\text { Recommended Levels } \\
\text { of Nutrients }\left(\mathrm{kg} \mathrm{ha}^{1}\right)\end{array}$} & \multirow{2}{*}{$\begin{array}{c}\text { Date of } \\
\text { Transplan } \\
\text { ting }\end{array}$} & & \multirow[t]{2}{*}{$\begin{array}{l}\text { Duration } \\
\text { in days }\end{array}$} & \multicolumn{4}{|c|}{$\begin{array}{c}\text { Recommended Levels of } \\
\text { Nutrients }\end{array}$} & \multirow[t]{2}{*}{$\begin{array}{l}\text { Date of } \\
\text { sowing }\end{array}$} \\
\hline & & & $\mathrm{N}$ & $\mathrm{P}$ & $\mathrm{K}$ & $\mathrm{Zn}$ & & & & $\mathrm{N}$ & $\mathrm{P}$ & $\mathrm{K}$ & $\mathrm{Zn}$ & \\
\hline Veral & Ratnagiri-4 & 125 & 100 & 50 & 50 & 20 & 16-Jully & Dapoli-1 & 100 & 25 & 50 & 0 & 0 & 16-November \\
\hline Asage & Ratnagiri-4 & 125 & 100 & 50 & 50 & 20 & 18-Jully & Dapoli-1 & 100 & 25 & 50 & 0 & 0 & 18-November \\
\hline Panhale & Ratnagiri-4 & 125 & 100 & 50 & 50 & 20 & 19-Jully & Dapoli-1 & 100 & 25 & 50 & 0 & 0 & 21-November \\
\hline Unhale & Ratnagiri-4 & 125 & 100 & 50 & 50 & 20 & 15-Jully & Dapoli-1 & 100 & 25 & 50 & 0 & 0 & 17-November \\
\hline Parule & Ratnagiri-4 & 125 & 100 & 50 & 50 & 20 & 05-Jully & Dapoli-1 & 100 & 25 & 50 & 0 & 0 & 15-November \\
\hline Shedhe & Ratnagiri-4 & 125 & 100 & 50 & 50 & 20 & 06.Jully & Dapoli-1 & 100 & 25 & 50 & 0 & 0 & 22-November \\
\hline
\end{tabular}


Table.3 Effect of NPK and Zn on rice-horse gram cropping system on rice equivalent yield (SREY) $\mathrm{kg} / \mathrm{ha}^{-1}$ at farmer's field

\begin{tabular}{|c|c|c|c|c|c|c|c|}
\hline \multirow[t]{2}{*}{ Location } & \multicolumn{6}{|c|}{ System rice equivalent yield (SREY) Kg / ha } & \multirow[b]{2}{*}{ FFMP } \\
\hline & control & $\mathrm{N}$ alone & With P & With K & With PK & $\begin{array}{l}\text { With PK } \\
\text { and } \mathrm{Zn}\end{array}$ & \\
\hline Veral & 2900.2 & 3621.8 & 3880.4 & 3869.3 & 5072.4 & 5741.2 & 4436.8 \\
\hline Asage & 2879.7 & 3684.9 & 4270.2 & 4107.0 & 4786.3 & 5889.0 & 4242.6 \\
\hline Panhale & 2730.3 & 3693.1 & 4410.8 & 4201.7 & 4710.2 & 6105.2 & 4205.2 \\
\hline Unhale & 2683.1 & 3810.6 & 4217.0 & 4183.9 & 5095.0 & 5817.2 & 4379.9 \\
\hline Parule & 2784.9 & 3662.0 & 4041.1 & 3952.7 & 4881.0 & 5705.8 & 4355.9 \\
\hline Shedhe & 2752.2 & 3731.2 & 4002.5 & 3938.3 & 4994.1 & 5638.8 & 4193.2 \\
\hline
\end{tabular}

Table.4 Partial Factor Productivity (PFP) of nitrogen ( $\mathrm{kg}$ grain $\mathrm{kg}^{1}$ nutrient applied) of rice - Horse gram cropping system in Ratnagiri district of Maharashtra

\begin{tabular}{|c|c|c|c|c|c|c|c|c|c|c|c|c|}
\hline \multirow[t]{3}{*}{ Location } & \multicolumn{6}{|c|}{ Kharif Rice } & \multicolumn{6}{|c|}{ Horse gram } \\
\hline & \multicolumn{12}{|c|}{ Partial Factor Productivity of N $\left(\mathrm{PFP}_{n}\right)$} \\
\hline & $\mathrm{N}$ alone & $\begin{array}{c}\text { With } \\
\text { P }\end{array}$ & $\begin{array}{c}\text { With } \\
\text { K }\end{array}$ & $\begin{array}{l}\text { With } \\
\text { PK }\end{array}$ & $\begin{array}{c}\text { With PK } \\
\text { and } \mathrm{Zn}\end{array}$ & $\begin{array}{c}\text { With } \\
\text { FP }\end{array}$ & $\mathrm{N}$ alone & With P & $\begin{array}{c}\text { With } \\
\text { K }\end{array}$ & $\begin{array}{c}\text { With } \\
\text { PK }\end{array}$ & $\begin{array}{c}\text { With PK } \\
\text { and } \mathrm{Zn}\end{array}$ & $\begin{array}{c}\text { With } \\
\text { FP }\end{array}$ \\
\hline Veral & 28.12 & 29.55 & 29.66 & 39.17 & 44.63 & 42.62 & 16.31 & 19.98 & 19.10 & 23.75 & 25.56 & 42.03 \\
\hline Asage & 28.50 & 32.88 & 31.74 & 36.53 & 46.22 & 40.49 & 17.14 & 20.52 & 19.21 & 24.41 & 24.44 & 42.83 \\
\hline Panhale & 28.64 & 34.14 & 32.63 & 36.23 & 48.02 & 40.07 & 16.81 & 20.37 & 18.93 & 22.75 & 24.84 & 42.94 \\
\hline Unhale & 29.58 & 32.37 & 32.54 & 39.09 & 45.17 & 41.82 & 17.14 & 20.58 & 18.52 & 24.91 & 26.09 & 43.67 \\
\hline Parule & 28.24 & 30.87 & 30.61 & 37.46 & 44.50 & 41.54 & 17.35 & 20.48 & 18.20 & 23.94 & 24.88 & 44.22 \\
\hline Shedhe & 28.68 & 30.57 & 30.51 & 38.41 & 43.79 & 39.66 & 18.02 & 20.21 & 17.99 & 24.01 & 25.28 & 45.24 \\
\hline
\end{tabular}


Table.5 Agronomic use efficiency (AUE) of Nitrogen ( $\mathrm{kg}$ increased grain yield $\mathrm{kg}{ }^{1}$ nutrient applied) of rice - Horse gram cropping system in Ratnagiri district of Maharashtra

\begin{tabular}{|c|c|c|c|c|c|c|c|c|c|c|c|c|}
\hline \multirow[t]{3}{*}{ Location } & \multicolumn{6}{|c|}{ Kharif Rice } & \multicolumn{6}{|c|}{ Horse gram } \\
\hline & \multicolumn{12}{|c|}{ Agronomic use efficiency (AUE) of $\mathrm{N}$} \\
\hline & $\begin{array}{c}\mathrm{N} \\
\text { alone }\end{array}$ & With P & $\begin{array}{c}\text { With } \\
\text { K }\end{array}$ & $\begin{array}{l}\text { With } \\
\text { PK }\end{array}$ & $\begin{array}{l}\text { With PK } \\
\text { and Zn }\end{array}$ & $\begin{array}{c}\text { With } \\
\text { FP }\end{array}$ & $\mathrm{N}$ alone & With P & $\begin{array}{l}\text { With } \\
\text { K }\end{array}$ & With PK & $\begin{array}{l}\text { With PK } \\
\text { and } \mathrm{Zn}\end{array}$ & $\begin{array}{c}\text { With } \\
\text { FP }\end{array}$ \\
\hline Veral & 5.06 & 6.50 & 6.60 & 16.11 & 21.58 & 14.67 & 5.63 & 9.30 & 8.42 & 13.08 & 14.89 & 15.34 \\
\hline Asage & 5.50 & 9.87 & 8.74 & 13.53 & 23.22 & 12.61 & 6.96 & 10.34 & 9.03 & 14.23 & 14.26 & 17.38 \\
\hline Panhale & 7.10 & 12.60 & 11.09 & 14.69 & 26.48 & 13.96 & 7.01 & 10.56 & 9.12 & 12.94 & 15.03 & 18.42 \\
\hline Unhale & 8.45 & 11.24 & 11.41 & 17.96 & 24.04 & 16.21 & 6.63 & 10.06 & 8.01 & 14.40 & 15.58 & 17.38 \\
\hline Parule & 5.94 & 8.56 & 8.30 & 15.16 & 22.19 & 14.50 & 7.16 & 10.29 & 8.01 & 13.75 & 14.69 & 18.74 \\
\hline Shedhe & 6.86 & 8.75 & 8.69 & 16.59 & 21.97 & 13.22 & 7.90 & 10.09 & 7.87 & 13.89 & 15.16 & 19.95 \\
\hline
\end{tabular}

Table.6 Relative response of treatments over control of rice - horse gram cropping system in Ratnagiri district of Maharashtra

\begin{tabular}{|c|c|c|c|c|c|c|}
\hline \multirow{2}{*}{ Location } & \multicolumn{6}{|c|}{ Relative response } \\
\hline & $\mathrm{N}$ & NP & NK & NPK & $\begin{array}{c}\text { With NPK and } \\
\text { Zn }\end{array}$ & FP \\
\hline Veral & 0.25 & 0.34 & 0.33 & 0.75 & 0.98 & 0.53 \\
\hline Asage & 0.28 & 0.48 & 0.43 & 0.66 & 1.05 & 0.47 \\
\hline Panhale & 0.35 & 0.62 & 0.54 & 0.73 & 1.24 & 0.54 \\
\hline Unhale & 0.42 & 0.57 & 0.56 & 0.90 & 1.17 & 0.63 \\
\hline Parule & 0.31 & 0.45 & 0.42 & 0.75 & 1.05 & 0.56 \\
\hline Shedhe & 0.36 & 0.45 & 0.43 & 0.81 & 1.05 & 0.52 \\
\hline
\end{tabular}


Table.7 Effect of N, P, K, and Zn on cost of cultivation (Rs/ha) and gross returns (Rs/ha) of rice - Horse gram cropping system in Ratnagiri district of Maharashtra

\begin{tabular}{|c|c|c|c|c|c|c|c|c|c|c|c|c|c|c|}
\hline \multirow[t]{2}{*}{ Location } & \multicolumn{7}{|c|}{ Cost of Cultivation (Rs/ha) } & \multicolumn{7}{|c|}{ Gross Returns (Rs/ha) } \\
\hline & Control & $\mathrm{N}$ & NP & NK & NPK & NPK Zn & FFM & Control & $\mathrm{N}$ & NP & NK & NPK & NPK Zn & FFM \\
\hline Veral & 82752.4 & 102243.7 & 110295.4 & 107550.8 & 115090.2 & 117817.0 & 103676.2 & 76566 & 114250 & 135396 & 131675 & 150949 & 162024 & 117062 \\
\hline Asage & 82434.2 & 102211.9 & 110236.1 & 110389.5 & 115335.4 & 117089.7 & 103755.9 & 75035 & 113446 & 134179 & 130213 & 150628 & 158171 & 117736 \\
\hline Panhale & 82305.2 & 102137.6 & 110522.2 & 107379.5 & 114542.8 & 117421.9 & 103914.3 & 74396 & 111024 & 136663 & 131368 & 145210 & 159194 & 118890 \\
\hline Unhale & 82613.3 & 102205.8 & 110534.0 & 107061.4 & 115613.1 & 117971.2 & 104234.7 & 77883 & 113434 & 136471 & 128066 & 154886 & 163453 & 118331 \\
\hline Parule & 82602.2 & 102101.6 & 110863.9 & 107690.1 & 115506.0 & 117242.3 & 103435.7 & 75420 & 112897 & 138923 & 133685 & 154257 & 157543 & 116593 \\
\hline Shedhe & 82404.3 & 102421.1 & 110773.2 & 107390.1 & 115148.3 & 117271.3 & 103769.6 & 75573 & 117427 & 140682 & 131789 & 150317 & 156555 & 117929 \\
\hline
\end{tabular}

Table.8 Effect of N, P, K, and Zn on net returns (Rs/ha) and B:C ratio of rice - Horse gram cropping system in Ratnagiri district of Maharashtra

\begin{tabular}{|c|c|c|c|c|c|c|c|c|c|c|c|c|c|c|}
\hline \multirow[t]{2}{*}{ Location } & & & & \multicolumn{3}{|c|}{ Net Returns (Rs/ha) } & \multirow[b]{2}{*}{ FFMP } & \multirow[b]{2}{*}{ Control } & \multirow[b]{2}{*}{$\mathrm{N}$} & \multirow[b]{2}{*}{$\mathrm{NP}$} & \multicolumn{2}{|r|}{ B:C Ratio } & \multirow[b]{2}{*}{ NPK Zn } & \multirow[b]{2}{*}{ FFMP } \\
\hline & Control & $\mathrm{N}$ & NP & NK & NPK & NPK Zn & & & & & NK & NPK & & \\
\hline Veral & -6186.3 & 12006.5 & 25100.9 & 24124.0 & 35858.8 & 44206.9 & 13386.2 & 0.93 & 1.12 & 1.23 & 1.22 & 1.31 & 1.38 & 1.13 \\
\hline Asage & -7398.9 & 11234.0 & 23943.2 & 19823.5 & 35292.1 & 41080.9 & 13980.1 & 0.91 & 1.11 & 1.22 & 1.18 & 1.31 & 1.35 & 1.13 \\
\hline Panhale & -7909.0 & 8886.1 & 26140.7 & 23988.5 & 30667.4 & 41771.6 & 14975.9 & 0.90 & 1.09 & 1.24 & 1.22 & 1.27 & 1.36 & 1.14 \\
\hline Unhale & -4730.2 & 11228.2 & 25936.7 & 21004.9 & 39273.0 & 45482.1 & 14096.3 & 0.94 & 1.11 & 1.23 & 1.20 & 1.34 & 1.39 & 1.14 \\
\hline Parule & -7181.8 & 10795.8 & 28059.4 & 25994.6 & 38750.8 & 40300.3 & 13157.7 & 0.91 & 1.11 & 1.25 & 1.24 & 1.34 & 1.34 & 1.13 \\
\hline Shedhe & -6830.8 & 15006.2 & 29908.9 & 24398.5 & 35169.0 & 39283.3 & 14159.3 & 0.92 & 1.15 & 1.27 & 1.23 & 1.31 & 1.33 & 1.14 \\
\hline
\end{tabular}

Table.9 Marginal returns (MR) (\%) due to application of $\mathrm{N}$ with $\mathrm{P}$ and $\mathrm{K}$ over control in rice - horse gram cropping system in Ratnagiri district of Maharashtra

\begin{tabular}{|c|c|c|c|c|c|c|}
\hline \multirow[t]{2}{*}{ Location } & \multicolumn{6}{|c|}{ Marginal returns (MR) (\%) } \\
\hline & $\mathrm{N}$ & NP & NK & NPK & With NPK and Zn & $\mathrm{FP}$ \\
\hline Veral & 93 & 114 & 122 & 130 & 144 & 34 \\
\hline Asage & 94 & 113 & 97 & 130 & 140 & 31 \\
\hline Panhale & 85 & 121 & 127 & 120 & 141 & 33 \\
\hline Unhale & 81 & 110 & 105 & 133 & 142 & 43 \\
\hline Parule & 92 & 125 & 132 & 140 & 137 & 29 \\
\hline Shedhe & 109 & 130 & 125 & 128 & 132 & 34 \\
\hline
\end{tabular}


Similar trend was noticed in case of net returns it was comparatively higher at all the locations with NPK application along with $\mathrm{ZnSO}_{4}$ compared to control, $\mathrm{N}$ alone, NP, NK and NPK combinations. Marginal returns (Table 9) were found to be higher with combined application of $\mathrm{NPK}+\mathrm{ZnSO}_{4}$ than $\mathrm{N}$ alone, NP, NK and NPK. Among the villages, Veral location of Lanja block recorded highest (144\%) marginal returns under balanced application followed village Unhale of Rajapur block (142\%) of rice -horse gram cropping system in study area. Application of $\mathrm{N}$ alone, NP, NK and NPK recorded lower marginal returns at all the location by reaming treatment as compared to balanced application of nutrients, these results are on same line ass by Raghuveer Singh et al., (2017).

With aim to improve productivity, use efficiency and returns from rice-horse gram cropping system in the south konkan region an appropriate balanced application of recommended quantity of NPK with micronutrients is essential. Thus, it can be concluded that application of recommended quantity of nitrogen, phosphorus and potassium together with supplementation of location specific deficient micronutrient is essential for getting higher productivity, profitability and to have proper response to applied.

\section{Acknowledgement}

The authors are highly thankful to Indian Council of Agricultural Research-Indian Institute of Farming Systems Research, Modipuram, UP, India for financial help in conducting the trials on farmer's field.

\section{References}

Anonymous, (2017) Maharashtra State Annual Rice Workshop Progress Report held during 10th march.
Ali, M. and Mishra, J.P. 2000. Nutrient management in pulses and pulse based cropping systems. Fertilizer News, 45:4: 57-69.

Dahiphale A.V., U.P Singh. Sanjeev Kumar Kashyap., Sandeep Kumar and Hari Singh. (2017) Precise nitrogen management: Away forward for enhancing resources use efficiency and productivity of direct seeded rice: A review. International Journal of Chemical Studies. 5:6: 1485-1493.

Dwivedi, B.S., Singh, V.K., Shekhawat, K., Meena, M.C., Dey, A. (2017) Enhancing use efficiency of phosphorus and potassium under different cropping systems of India. Indian J. Fertil. 13: 20-41.

Raghuveer Singh., Ravisankar, N. and Kamta Prasad. 2017. Improvement in productivity and economics of major food production systems of India through balanced dose of nutrients. Curr. Sci. 112: 12:2470-74.

Ravisankar, N., Gangwar, B. and Prasad, K. (2014) Influence of balanced fertilization on productivity and nutrient use efficiency of cereal based cropping systems. Indian J. Argic. Sci., 84: 24854.

Haerdter, R. and Fairhurst, T. (2003) Nutrient use efficiency in upland cropping systems of Asia. In IFA Regional Conference, Cheju Island, Korea, 6-8 October.

Gosh, P. K., Bandopadhay, K. K. Misra, A. K. and Rao, A. S. (2004) Balanced fertilization for maintaining soil health and sustainable agriculture. Fert. News, 49: 4:13-35.

Panwar, A.S., Shamim, M., Babu, S., Ravishankar, N., Prusty, A.K., Alam, N.M., Singh, D.K., Bindhu, J.S., Kaur, J., Dashora, L.N., Pasha, M.D.L., Chaterjee, S., Sanjay, M.T., Desai, L.J. (2019) Enhancement in Productivity, 
Nutrients Use Efficiency, and Economics of Rice-Wheat Cropping Systems in India through Farmer's Participatory Approach. Sustainability 11:122. doi:10.3390/su11010122

Prasad, R., Kumar, D., Sharma, S. N., Gautam, R. C. and Dwivedi, M. K. (2004) Current status and strategies for balanced fertilization. Fert. News. 49 :12: 73-80.

Tittonell, P. B., Vanlauwe, M. C. and Giller,
K. E. (2008) Yield gaps, nutrient use efficiency and response to fertilizers by maize across heterogeneous small holder farms of western Kenya. Plant Soil, $313: 1-19$.

Yadav, R.L. (2003) Assessing on-farm efficiency and economics of fertilizers $\mathrm{N}, \mathrm{P}$ and $\mathrm{K}$ in rice-wheat system of India. Field Crops Res. 81: 39-51.

\section{How to cite this article:}

Dahiphale, A. V., S. B. Bhagat, N. V. Mhaskar, D. G. Jondhale, T. J. Bedse and Vanve, P. B. 2020. On-farm Assessment of Balanced Crop Nutrition on Productivity and Nutrient Use Efficiency in Rice (Oryza sativa L.) - Horse Gram [Macrotyloma uniflorum (Lam.) Verdc] Cropping System in South Konkan Coastal Zone of Maharashtra. Int.J.Curr.Microbiol.App.Sci. 9(05): 2250-2259. doi: https://doi.org/10.20546/ijcmas.2020.905.256 